\title{
An Investigation of the Factors That Motivated Illegal Settlements in the Mau Forest, Kenya
}

\author{
Alice Jebiwott ${ }^{1}\left(\mathbb{D}\right.$, George Morara Ogendi $^{2}$, Abiodun Akintunde Alo ${ }^{3}$, Ronald Kibet ${ }^{1}$ \\ ${ }^{1}$ Pan African University Life and Earth Sciences Institute (PAULESI), University of Ibadan, Ibadan, Nigeria \\ ${ }^{2}$ Department of Environmental Science, Egerton University, Egerton, Kenya \\ ${ }^{3}$ Department of Forest Resource Management, University of Ibadan, Ibadan, Nigeria \\ Email: aliciaphil.chebby@gmail.com,gmorara2009@gmail.com, akintundealodaniel@gmail.com,ronaldlangatkip@gmail.com
}

How to cite this paper: Jebiwott, A., Ogendi, G.M., Alo, A.A. and Kibet, R. (2021) An Investigation of the Factors That Motivated Illegal Settlements in the Mau Forest, Kenya. Open Journal of Ecology, 11, 725-740. https://doi.org/10.4236/oje.2021.1111045

Received: September 16, 2021

Accepted: November 6, 2021

Published: November 9, 2021

Copyright (c) 2021 by author(s) and Scientific Research Publishing Inc. This work is licensed under the Creative Commons Attribution International License (CC BY 4.0).

http://creativecommons.org/licenses/by/4.0/

(c) (i) Open Access

\begin{abstract}
The Mau Forest has in the recent past elicited serious political and environmental debates regarding its conservation status, as the forest is fast dwindling and the repercussions felt widely across the country. The forest, regarded as the largest indigenous montane forest in east Africa, has been hard hit by land-use changes mainly extensive and ill-planned human settlements. To save the forest, the government has resorted to forced evictions of the settlers. We sought to understand the drivers and causes for the observed illegal settlements in the Mau Forest. To collect data, we conducted focus group discussions and administered household questionnaires on evictees in the South-West and Eastern Mau. Data were analyzed using descriptive and inferential statistics. The results of the binary logistic regression model indicate that Poverty $(\mathrm{p}=0.000)$, Agricultural production $(\mathrm{p}=0.000)$ and Land Given by Government $(\mathrm{p}=0.018)$ contributed significantly to the prediction of people's motivation of settling in the Mau Forest. In conclusion, population pressure, laxity in forest law enforcement and insecure land tenure and politics were identified as some of the factors that motivated the observed rise in illegal settlements in Mau Forest. Such information on the factors that led to the illegal settlements in Mau Forest would be useful for forest conservation policy makers and managers. It will be a basis upon which interventions can be undertaken to enhance sustainable forest management in Kenya and beyond.
\end{abstract}

\section{Keywords}

Mau Forest, Logistic Regression, Illegal Settlements, Forest Conservation, Eviction 


\section{Introduction}

Forests provide us with various ecosystem goods and services that support our wellbeing and livelihoods. Jenkins \& Schaap [1], estimate that over $1.6 \mathrm{~B}$ people worldwide rely on forest ecosystems for their livelihood. Of these, forest-dwelling native peoples and rural communities who live in proximity to the forest constitute about 300 - 350 million people, and nearly all completely rely on the forests for their wellbeing. The rest of the forest users include people living in urban and rural areas. Ecosystem services derived from the forest include fuelwood, fiber, construction material, herbal medicine, honey, fodder and water among other services [2] [3]. According to Jenkins \& Schaap [1], forests are an important income generator especially to rural families in Africa, Asia and Latin America. People living in and around the forests benefit from the forest through logging, practicing crop farming and livestock keeping on forestland, and utilization of non-timber forest products [4]. All these activities help alleviate poverty by generating cash and non-cash incomes which improve their wellbeing [5] [6]. Consequently, the forest-dependent population in developing countries has risen out of extreme poverty as a result of the income generated from the forest ecosystem services [7].

Despite recognizing the importance of forests in the ecosystem, forest degradation and deforestation continue to occur at unprecedented rates. Forest destruction is a result of several direct and indirect drivers. Various studies have investigated the drivers of forest degradation and identified anthropogenic activities as the leading cause of forest degradation and deforestation [8]. A study carried out in Myanmar (Burma) identified the main causes of forest degradation as agricultural extension, infrastructure development, mining, corruption, and economic pressure [9]. Elsewhere in Vietnam, poverty, population growth, and agricultural expansion were the significant causes of deforestation and forest degradation in the country. These factors accounted for 1.77 million ha of forest loss and 0.65 million ha of degraded forests in Vietnam [10]. However, these drivers vary depending on various local conditions. Therefore, the scientific community would be unjustified if it draws generalized conclusions on drivers of deforestation and forest degradation.

In Africa, for example, Kissinger et al. [11], notes that, extraction of firewood and charcoal production are the main factors driving forest degradation and deforestation. Agricultural production, mostly small-scale farming, also contributes majorly to deforestation in Africa. According to [12] and [13], food consumption is expected to double by the year 2050, and most of these increases will be consumed in developing nations owing to their increased populations and living standards. They note that one of the ways to increase food production is through intensification of agricultural practices and this calls for more land which can potentially lead to increased deforestation in some situations. Nasi et al. [14], points out that, though the drivers of deforestation and degradation have been documented, it is also important to know why each of the driving factors occur. 
Several nations have identified weak institutional frameworks and poor governance as underlying forces. Poor law enforcement results in illegal forest activities such as the extension of agricultural lands, logging and illegal settlements. Another major underlying cause for deforestation is poverty, which leads to people clearing forest lands for agricultural production or overharvesting of forest resources for sale or consumption [15]. Other notable causes include population growth and insecurity of land tenure [16] [17].

In Kenya, forest degradation and deforestation continue to present a significant challenge for forest conservation efforts. According to the Global Forest Watch report [18], between the period of 2002 and 2020, Kenya lost approximately $14 \%$ of its total forest cover. Of these losses, $2.6 \%$ of tree cover loss happened in areas where there were dominant drivers of forest degradation and deforestation. The major drivers identified were urbanization, subsistence, and commercial driven deforestation and land encroachment, mainly for agricultural purposes. In another study by Mulinge et al. [19], forest degradation and deforestation in Kenya can be attributed to population growth and changing land-use patterns. According to Nasi et al. [14], some of the activities which include logging, overharvesting of non-timber forest products, infrastructural developments, overgrazing and conversion of forests to agricultural lands, may partially or completely lead to the removal of forest cover. The changes in forest cover lead to altered forest structure which in turn reduces the ability of the forest to perform its functions. Olander et al. note that the multiple impacts of forest degradation are felt at various levels. These impacts include environmental, social, and economic challenges [20].

Mau forest, an important water catchment area in Kenya, has been receding and this has fueled debates and political attention owing to the importance of this montane forest as a water tower, not only in Kenya but in Eastern Africa at large. The deforestation and degradation are believed to have been largely caused by the high number of human settlements within the forest. As people moved to settle in the forest, they cleared huge tracts of forestland to get space for their homesteads as well as for practicing agriculture and infrastructural developments. Moreover, the dependence on forest ecosystem services such as firewood, fodder, building materials and water among other services, increased leading to further degradation and deforestation. To save the forest from further destruction, the government has resorted to forceful evictions of the illegal settlers. Nevertheless, it is important to consider the factors that motivated those people to settle in the forest in the first place. This will help the government and the forest conservation authorities to find ways of harmonizing forest conservation and social development. In the long run, this will help avoid resentments from the evictees which may jeopardize the restoration efforts. Therefore, the issue at hand is one that is in dire need of close scrutiny but has often been ignored, and it is against this background that this research aimed to investigate the factors that motivated illegal settlements in Mau Forest. 


\section{Methodology}

\subsection{Study Area}

The Mau Forest Complex (Figure 1), gazzeted in 1954 as forest reserve, is the largest indigenous, closed canopy forest in Kenya. It is also the largest of the five water catchments in Kenya, commonly referred to as the water towers. The complex is situated in the rift valley province of Kenya, about $170 \mathrm{~km}$ northwest of Nairobi. It straddles across four counties; Bomet to the southwest, Kericho to the west, Nakuru to the north and Narok to the south. The complex comprises of seven forest blocks namely; Eastern Mau, Western Mau, South-West Mau, Oldonyo Puro, Maasai Mau, Southern Mau and Transmara. The forest plays a significant role not only in supporting the livelihoods of the forest adjacent communities but also in supporting key sectors of the country's economy particularly agriculture, energy, tourism and water supply. Many rivers originate from the forest and these rivers, in turn, feed major lakes in Kenya and beyond, including lakes Nakuru, Victoria, Baringo and Natron.

Mau forest complex is home to the Ogiek indigenous community. The community who are mainly hunters and gatherers, have lived in the forest since time immemorial and hence derive their livelihood from the forest. Moreover, the forest

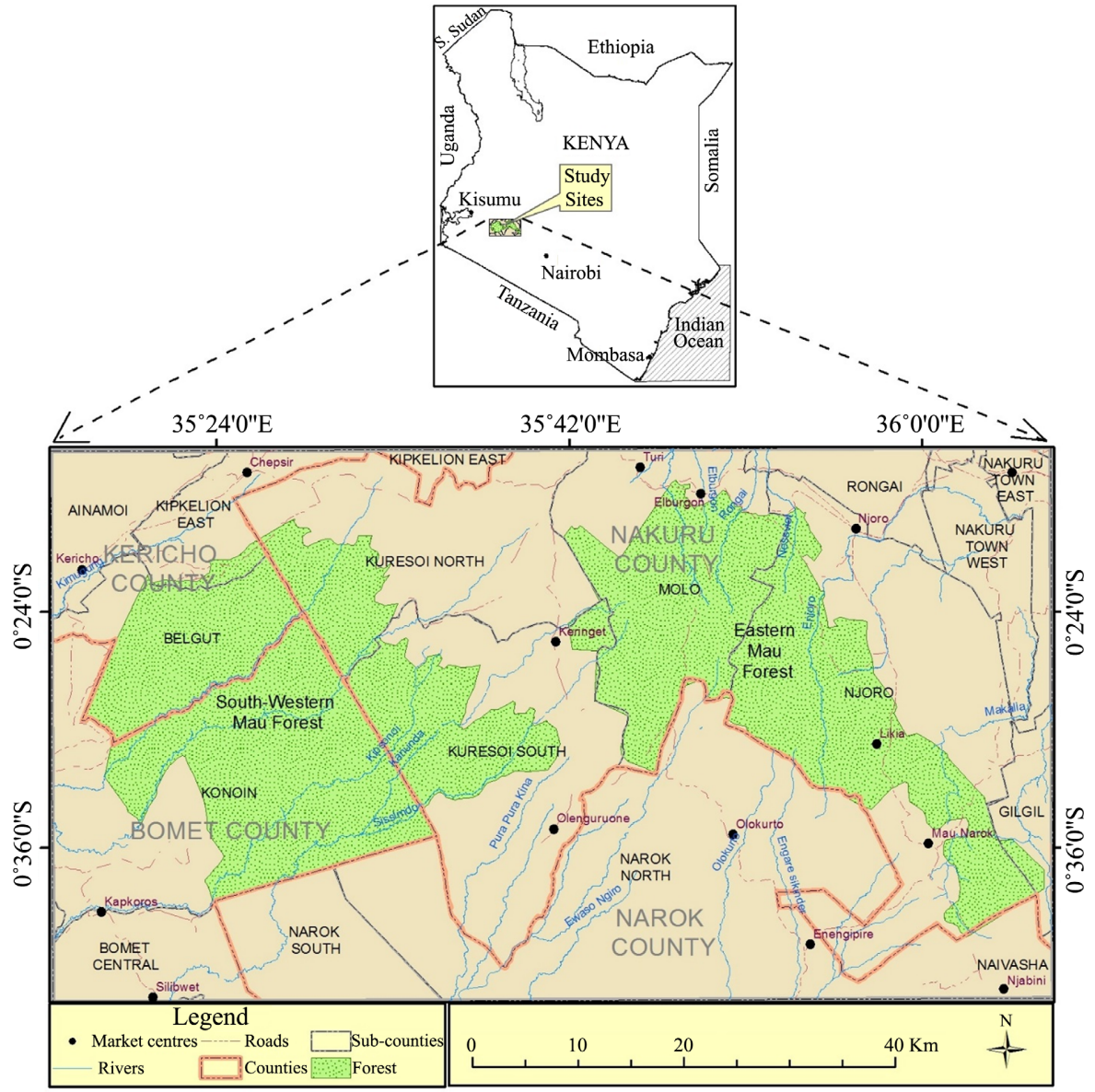

Figure 1. Map of study area-Mau Forest (Source: Author). 
is a key diversity area hosting some of the rare species of flora, avifauna and fauna. Some of the rare animals found in the forest include the yellow-backed duiker (Cephalophus silvicultor), mountain bongo (Tragelaphus eurycerus isaaci) and the African golden cat (Caracal aurata). The bird species include the Semi-Collared flycatcher (Ficedula semitorquata) and the Pallid harrier (Circus macrourus). In addition, rare indigenous trees such as red cedar (Juniperus procera), African olive (Olea africana), parasol tree (Polyscias kikuyuensis), black ironwood (Olea capensis), red stinkwood (Prunus africana) and East African yellow-wood (Podocarpus latifolius) are found in the forest. All these unique features make the Mau Forest ecosystem an important resource base not only for the local communities but also for the national and international community. The forest has however receded from its previous forest area coverage owing to deforestation and degradation caused by anthropogenic activities mostly human settlements.

\subsection{Data Collection}

The survey involved two sampling techniques; Purposive and Snowball sampling. Purposive sampling was used to select the study areas as places where the evictees settled or were resettled. Therefore, the study concentrated mainly on the Mau Forest blocks where eviction has taken or is taking place, that is, the South-West Mau and Eastern Mau. The issue of eviction being a sensitive topic, household and focus group discussion participants' selections was done through snowball sampling, where volunteers willing to participate in the survey were identified and the subsequent willing participants identified through referrals. A total of 321 households, 160 in South-West Mau and 161 in Eastern Mau, were sampled in this study. Structured and unstructured questionnaires were administered to representatives of households who participated in the study.

\subsection{Data Analysis}

The study employed both descriptive and inferential statistics in analyzing the data. To describe the data, frequencies and percentages were used. Results were presented in charts and graphs. Chi-square was used to test if there was any significant relationship between variables. To identify the factors that likely led to people settling in the forest, a binary logistic regression was carried out. The responses of the participants as to whether there was a presence or absence of a motivation to settle in the forest were framed as a binary choice, "No" and "Yes" (with "No" to indicate the absence and "Yes" to indicate the presence of a factor) and coded as 0 and 1 respectively. The probability of a response falling into either of the two categories mentioned was predicted using the factors "Poverty" (PO), "Land Availability" (LAV), "Land Affordability" (LAF), "Agricultural Production" (AP), "Land Scarcity" (LS) and "Given by Government" (GBG) which are the independent variables. The respondents recruited into the study were evaluated on the presence or absence of a motivation to settle in the forest. Therefore, a respondent that answered "yes" to a factor that led to people settling in Mau Forest were assigned values of 1 and those that said "no" were assigned values of 0 . A binary logistic re- 
gression was then run using the Statistical Package for the Social Sciences (SPSS) software to determine whether the probability of settling in Mau Forest could be predicted from the listed independent variables and this was represented as:

$$
\log (p / 1-p)=b 0+b 1 * x 1+b 2 * x 2+b 3 * x 3 \cdots b n * x n
$$

where $p=$ Motivation for settling in the Mau Forest (dependent variable).

$b=$ regression parameters.

$x=$ factors that led to settling in Mau Forest (independent variables).

Expressed in terms of the variables used in this study, the logistic regression equation is

$$
\begin{aligned}
\log (p / 1-p)= & b 0+b 1(L A V)+b 2(L A F)+b 3(A P) \\
& +b 4(L S)+b 5(G B G)+b 6(P O)
\end{aligned}
$$

This equation shows the relationship between the independent variables and the dependent variable, where the dependent variable is on the logit scale. If the p-value is less than 0.05 for a coefficient then it is significant. An odds ratio of greater than 1 implies a positive relationship while an odds ratio of less than 1 implies a negative association.

\section{Results and Discussion}

\subsection{Socioeconomic Characteristics of the Respondents}

Of the 321 sampled respondent $54.7 \%$ were male and $45.3 \%$ female. Most (54.7\%) of the respondents were between the ages of $35-49$, and $9.9 \%$ were above 65 years. Their education levels varied considerably with $4.3 \%$ having up to tertiary level of education and $59.7 \%$ primary education. Their household sizes were varied as shown in Figure 2. Most of the households in the study area consisted of 6 to 10 members.

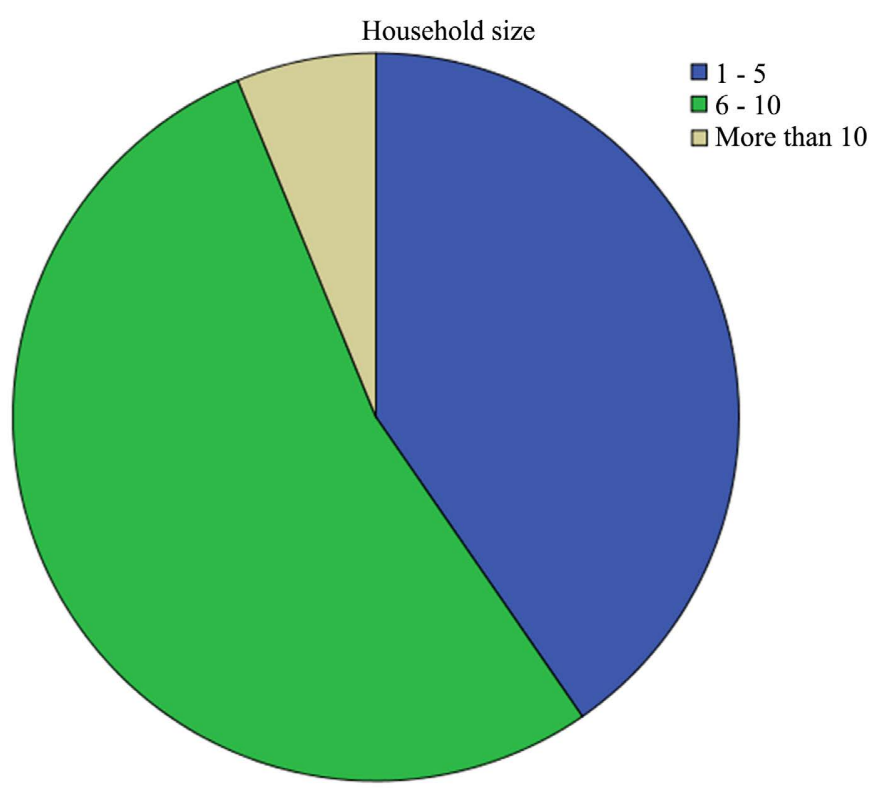

Figure 2. A chart showing household size. 


\subsection{Sources of Livelihood}

The major sources of income for the respondents were farming (49.7\%) and casual work (44.7\%). Professional job (4.3\%) and business (1.2\%) were the least sources of income. The chi-square test of association, $\chi^{2}=194.87, \mathrm{df}=12, \mathrm{p}=$ 0.000 , revealed that there was a statistically significant association between education level and source of income. This analysis tells us that the large number of incomes from casual labor and farming activities is because of the fact that most of the respondents were educated up to primary level and so they have no salaried jobs. The few who are educated up to secondary and tertiary levels are able to gain employment as they have the required skills. These findings are consistent with those of [21] who noted that there is disparity in income levels of various social classes depending on their education levels. Those who are highly educated are more productive and hence earn more than those with low levels of education. See Figure 3 below.

In terms of their monthly income, most of the respondents $(60.9 \%)$ were within the income bracket of less than five thousand Kenyan Shillings, those within a bracket of 5000 - 10,000 were 30.4\%, 10,001 - 20,000 were $6.8 \%$, and those above 20,000 were $1.9 \%$. This shows that majority $(60.9 \%)$ of the respondents are under extreme poverty as defined by World Bank since they live on less than 1.9 USD per day. Their low-income brackets could be attributed to the size of land they owned seeing that most relied on small scale farming and casual labor. Table 1 shows comparison data between income bracket and size of land owned by the respondent after eviction.

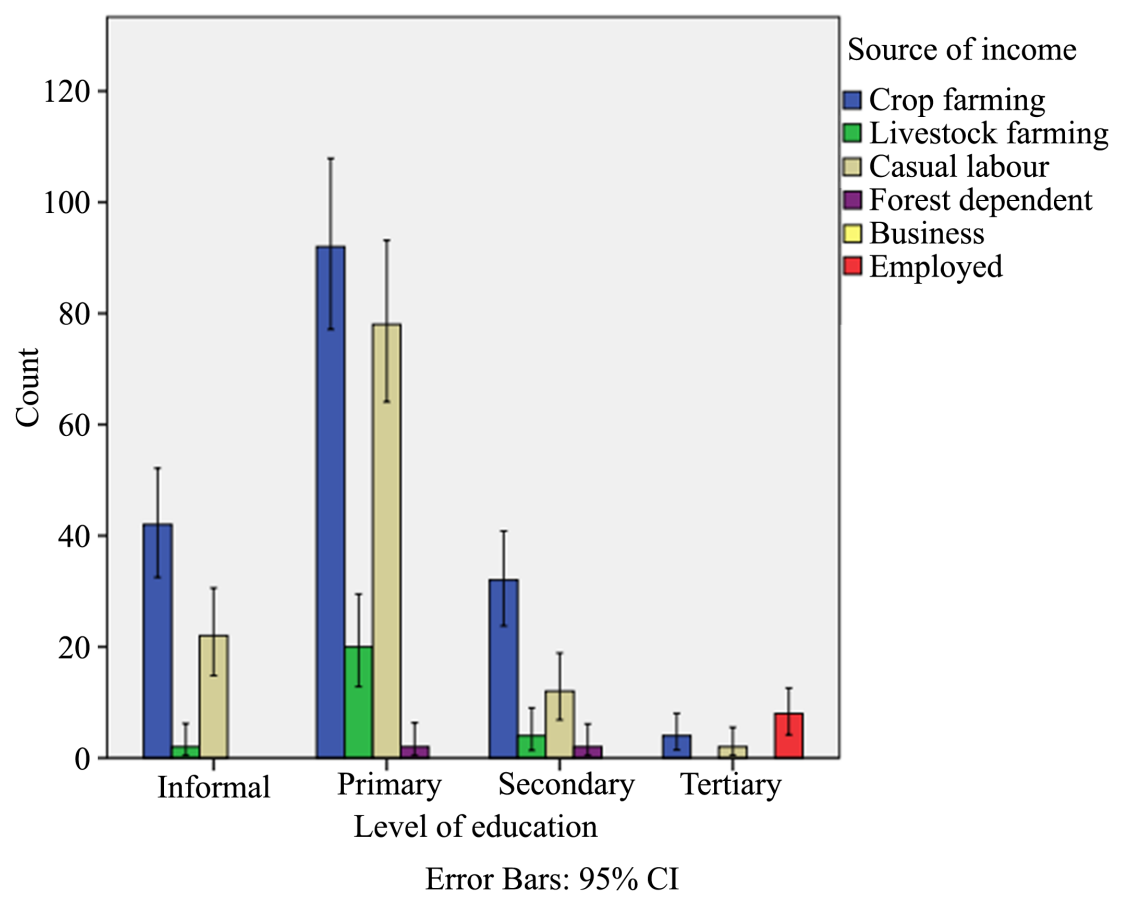

Figure 3. A graphical representation of various sources of income based on the level of education. 
Table 1. Size of land vs income bracket.

\begin{tabular}{|c|c|c|c|c|c|c|}
\hline \multicolumn{7}{|c|}{ Size of land owned now ${ }^{*}$ Income bracket Crosstabulation } \\
\hline \multicolumn{7}{|c|}{ Count } \\
\hline & & \multicolumn{4}{|c|}{ Income bracket } & \multirow[b]{2}{*}{ Total } \\
\hline & & $\begin{array}{c}\text { Less } \\
\text { than } 5 \mathrm{k}\end{array}$ & $5000-10,000$ & $10,000-20,000$ & $20,000-50,000$ & \\
\hline \multirow{5}{*}{$\begin{array}{c}\text { Size of } \\
\text { land } \\
\text { owned } \\
\text { now }\end{array}$} & $\begin{array}{l}\text { No land } \\
\text { (Squatter) }\end{array}$ & 62 & 44 & 12 & 2 & 120 \\
\hline & $\begin{array}{l}\text { Less than } \\
\text { one acre }\end{array}$ & 98 & 14 & 2 & 0 & 114 \\
\hline & $1-2$ acres & 30 & 22 & 8 & 0 & 60 \\
\hline & $3-4$ acres & 2 & 2 & 0 & 0 & 4 \\
\hline & $\begin{array}{c}5 \text { or } \\
\text { more acres }\end{array}$ & 10 & 6 & 4 & 4 & 24 \\
\hline \multicolumn{2}{|c|}{ Total } & 202 & 88 & 26 & 6 & 322 \\
\hline
\end{tabular}

The chi-square test of independence results $\left(\chi^{2}=73.82, \mathrm{df}=12, \mathrm{p}=0.000\right)$ indicates that there is a statistically significant association between this income bracket and the size of land owned. This implies that the landless and those with small land sizes earn less as they have no or little land to farm on, and others have to completely depend on casual labor. These findings are supported by those of [22] who found out that income from agriculture is higher when the size of land is big as compared to when the land size is small. Figure 4 shows the relationship between income bracket and size of land.

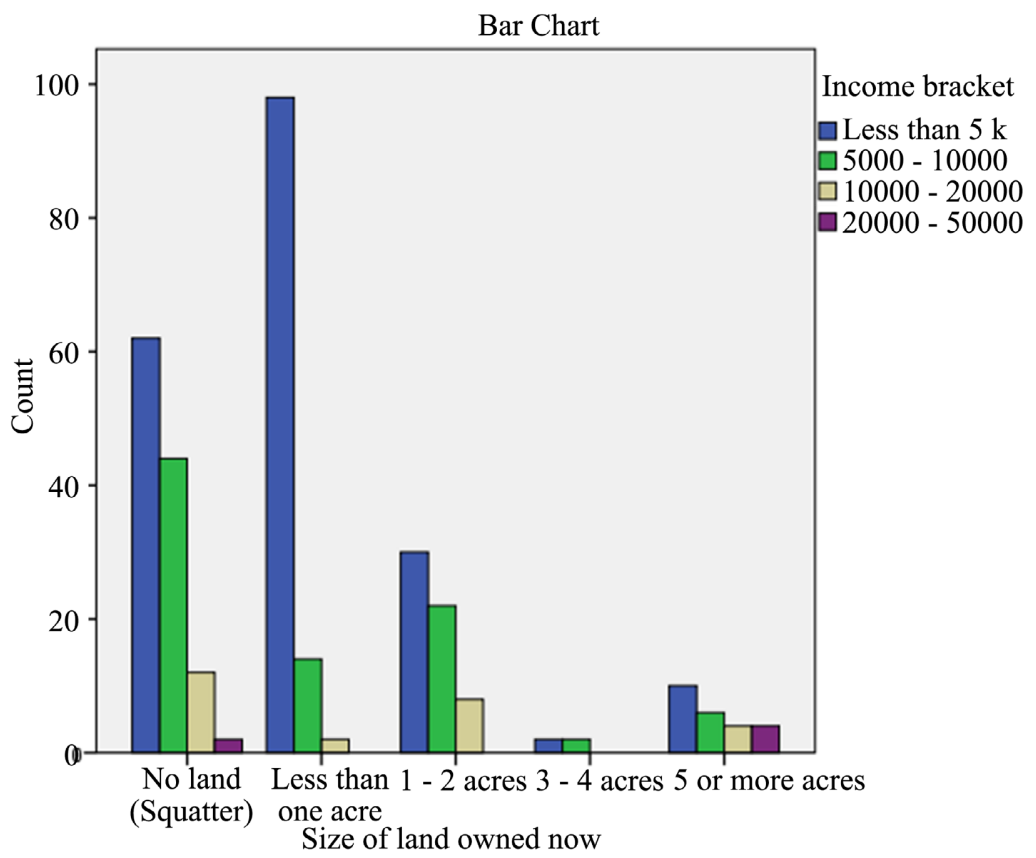

Figure 4. A graphical representation of the relationship between income bracket and size of land. 
According to the household results, $35.4 \%$ of the respondents were landless/squatters, $35.4 \%$ owned less than an acre piece of land, $18 \%$ owned between one to two acres, $3.1 \%$ owned between 3 - 4 acres and the rest $8.1 \%$ owned more than 5 acres.

\subsection{Factors That Influenced the Respondents to Settle in Mau Forest}

The logistic regression results indicated in Table 2 below show a summary of the results of binary logistic regression analysis run to determine the factors that motivated the households to settle in Mau Forest.

Based on the results shown in Table 2, Poverty $(\mathrm{p}=0.000)$, Agricultural production $(p=0.000)$ and Land Given by Government $(p=0.018)$ contributed significantly to the prediction of people's motivation of settling in the Mau Forest. Land Availability ( $p=0.619)$, Land Scarcity $(\mathrm{p}=0.634)$ and Land Affordability $(\mathrm{p}=0.999)$ on the other hand, did not have any significant contribution to the prediction of people settling in the forest. In terms of the odds ratio, Poverty (odds ratio $=0.001$ ), Land Given by Government (odds ratio $=0.16$ ) and Agricultural Production (odds ratio $=0.000$ ) had a negative impact on the likelihood of motivating one to settle in the Mau Forest. Land Availability (odds ratio = 2.001), Land Scarcity (odds ratio $=2.464$ ) and Land Affordability (odds ratio $=$ 1.002) had positive impacts on the likelihood of motivating one to settle in the

Table 2. Logistic regression table.

\begin{tabular}{|c|c|c|c|c|c|c|c|}
\hline \multicolumn{8}{|c|}{ Variables in the Equation } \\
\hline & & B & S.E. & Wald & $\mathrm{df}$ & Sig. & Exp (B) \\
\hline \multirow{7}{*}{ Step $1^{\mathrm{a}}$} & $\mathrm{PO}(1)$ & -7.423 & 1.467 & 25.589 & 1 & 0.000 & 0.001 \\
\hline & LAV(1) & 0.694 & 1.396 & 0.247 & 1 & 0.619 & 2.001 \\
\hline & $\mathrm{LS}(1)$ & 0.902 & 1.892 & 0.227 & 1 & 0.634 & 2.464 \\
\hline & $\operatorname{LAF}(1)$ & 0.002 & 1.843 & 0.000 & 1 & 0.999 & 1.002 \\
\hline & $\operatorname{AP}(1)$ & -7.915 & 1.524 & 26.964 & 1 & 0.000 & 0.000 \\
\hline & LGG(1) & -4.121 & 1.749 & 5.553 & 1 & 0.018 & 0.016 \\
\hline & Constant & 12.668 & 2.585 & 24.016 & 1 & 0.000 & $317,479.458$ \\
\hline
\end{tabular}

a. Variable(s) entered on step 1: PO, LAV, LS, LAF, AP, LGG.

Mau Forest. The values were however, not statistically significant at 5\% level implying that they cannot be generalized to the entire population of the inhabitants of Mau Forest.

Deforestation and forest degradation are often as a result of activities by a number of actors. These actors can be individuals or groups of persons who degrade the forest for various reasons and motivational factors within their social environments. The illegal forest settlers are agents of deforestation as they con- 
tribute to land use changes and eventual decline of forest cover. Empirical studies from across the World have given an indication that various motivations drive people to move to the forest habitats. With that in mind, there could be many factors that led the households to settle in Mau Forest.

The findings of the study established that the odds ratio of poverty as a factor that led to People settling in the forest was 0.001 to 1 , implying that there is a relatively low likelihood of poverty driving people to move into the forest, a finding that does not resonate exactly with the findings of [23], who carried out a household survey focusing on communities living in forests in Turkey. Their findings suggested some level of dependence of communities with poor background on Forest resources. Another study conducted by [24], is also contrary to this study's findings. They indicate that encroachers are characteristically poor people whose aim is to increase their income and therefore exploit the forest resources in form of illegal logging and extension of agricultural lands. According to Geist \& Lambin [25], poverty contributes to deforestation mainly in Africa. They cite that, due to population pressure, people resort to clearing of forest areas for agricultural production and eventually as a means of rising out of poverty. Although poverty is known to be a major driver of forest degradation and deforestation, in this study, the disadvantaged communities could still have practiced agriculture, logging, charcoal production, firewood harvesting among other illegal activities that cause deforestation and forest degradation, without necessarily settling within the forest.

The study findings as summarized in Table 2 also indicate that the odds ratio for Land Given by Government was $\beta_{7}=0.016$ which means that this factor had a low likelihood of motivating people to settle in Mau Forest. This could be possibly because land was allocated only to select people. According to the focus group discussion participants, prominent politicians acquired parcels of land in Mau Forest through unscrupulous ways. This finding is consistent with that of [26], who indicated that the government allotted parcels of forestlands in Mau Forest to private individuals as a form of political reward. This means that the local people did not benefit from these politically motivated allocations. In contrast to this finding, a report by [27], indicates that Vietnamese government has been allocating forestlands to the local communities in an effort to protect the forest and at the same time improve the people's standard of living.

With an odds ratio of 0.000 , Agricultural Productivity had a negative relationship with the motivation to settle in the forest. This implies that, an increasing agricultural productivity was associated with a reduction in the probability of a motivation to settle in the forest. From time to time, and contrary to the findings of this study, forest-related research has illustrated that agricultural productivity is one of the primary factors that drive people to encroach the forest ecosystems. One such study was observed in an empirical survey in Ghanaian forest reserves by [28] where it was established that the desire to improve crop farming motivates settlements and encroachment in the forest ecosystems. Whereas this is the case, in this study agriculture was not a motivating factor to settling in the 
forest. This may be because, the communities do not necessarily have to move into the forest to get agricultural land. On the contrary, one can still own agricultural land within the forest while residing outside of the forest.

Some of the responses from the focus group discussion and household questionnaires pointed at laxity on the part of the forest management authorities as a factor that may have led to illegal forest settlements in Mau. The decision to clear forestland for settlement is largely attributed to weak enforcement of forest laws and policies which make it easier for an individual to encroach the forest. This finding is similar to that of Ankomah et al. [29], who found out that low enforcement practices fueled by corruption on the part of forest officers was one of the major underlying causes of forest encroachment. Moreover, one of the household participants indicated that; "I cleared the forest so that I get the land" respondent no. 7, Simotwet Village, Eastern Mau, settled 1997, evicted 2012.

Another one yet indicated that "One of my relatives went to live in the forest thereafter come to inform me that there was availability of land in the forest" respondent no 5, Soet village, Eastern Mau, settled 2000 evicted 2012. These narrations show that law enforcement was not strict, otherwise, the respondents would not have settled in the forest for that long without the forest officers noticing it. According to a report by Standing \& Gachanja [26], corruption of forest officials and poor forest governance in the Kenyan forestry sector led to encroachments that resulted in loss of forests.

Another factor identified by the focus group discussion participants was population pressure. From the discussion we were able to gather information that there has been an increase in population which has led to land fragmentations and subdivisions. According to the discussion, as family sizes increased the size of land to be inherited by the heirs reduced as parental land has to be at least divided equally among the heirs. This means that the land becomes smaller and smaller and the subsequent generations are forced to look for land elsewhere. This finding is consistent with the findings from a survey conducted among different Communities living in the Amazon rainforest in South America by [30]. Their findings underscored lack of land as one of the reasons that lead people to settle in the forests. Moreover, [15] and [31], in their study found out that increase in population has got adverse effects on forest resources.

More so, in this study, the descriptive statistics reveal that $35.4 \%$ of the respondents were landless and another $35.4 \%$ owned less than an acre piece of land. This confirms that indeed population pressure was a problem as it had led to land fragmentations and even lack of land for most of the participants. This could have prompted the respondents to illegally settle in the forest. The results of this study are also supported by other past research studies that have suggested that unavailability of land drives people to move to the forest habitats. One such study is that of Iftekhar \& Hoque [32], whose findings indicated that limited land availability leads to forest encroachment. This scarcity of land is usually due to population pressure especially in larger households as there is low per capita in landholding, like in this study where many respondents recorded 
family sizes of 6 - 10 persons per household. According to one of the household participants in this study, land was not enough for all the siblings hence he opted to look for land elsewhere and that happened to be the forest.

"My family had small piece of land and I have 5 brothers so sharing that piece of land among ourselves of which each get a smaller share which made me move away and settle in the forest' respondent no 77 Simotwet village, Eastern Mau, settled 1998 evicted 2012.

Lastly, insecure land tenure and politics was also mentioned in the focus group discussion as another factor that may have motivated the evictees to illegally settle in the Mau Forest. According to the participants, wealthy and prominent politicians had allocated themselves huge parcels of land in Mau Forest. As a result, the locals felt that they were also entitled to own parcels of land in the forest and so they moved to clear and illegally settled in the forest as they saw it as a free land. This finding is consistent with that of the Ndung'u Commission report [33] who revealed that there were illegal and irregular allocations of public land, including the Mau Forest, to elite politicians. Moreover, the Ogiek indigenous people who consider the Mau Forest as their ancestral land have become victims of evictions from time to time. They are neither able to claim their identity nor customary territories as they are not recognized by law. This has opened up avenues for outsiders to settle in the forest and also claim that they are indigenous people while they are not. This finding is supported by the studies of Kariuki \& Ng'etich [34], who indicated that the Ogiek community have been forcefully evicted from their ancestral homes in Mau Forest putting their livelihoods at risk. According to the discussion, the politics and land tenure coupled with weak law enforcements rendered Mau Forest a nobody's land where everyone could go in and clear the forest as they wished, and others even cheaply sold it to unsuspecting buyers. This made the forest land affordable to many who could not otherwise afford land outside the forest, and this attracted many illegal settlers who came and illegally settled in the forest. This finding is in agreement with the findings of a study conducted by Palmer et al. [35], who focused on the issue of land tenure in several countries. They indicated that affordability of land is critical particularly when enforcing measures that would ensure protection of natural resources such as forests, especially with the aim to avoid instances of people moving into the forest in search of affordable land. From the household questionnaires conducted in this study, one of the respondents indicated that the land was sold to him at a cheap price and so this could have been a motivating factor.

"My father refused to give me my share in his land to live and therefore I decided to move and buy land from a relative who lived in the forest" respondent no 3, Sigaon village, Eastern Mau, settled 2001 evicted 2012.

\subsection{Implications on Policy Making}

Although eviction has taken place, there are several issues that have not been 
addressed and this may hamper the forest restoration efforts. It is important to address these important issues so as to achieve environmental and social sustainability. First, the forest adjacent communities should be actively involved in all forest management activities and decisions. This will make them feel that they own and have control over the forest hence addressing forest conservation through communal ownership and stewardship. Secondly, the government should address livelihood and land tenure issues. As the local population is increasing, they might exert pressure on the forest resources as a source of livelihood. To avoid this, the local communities should be educated on the importance of conserving the forest, and they should be granted access to forest resources to help them cope with hard times and thereby reducing their vulnerability to poverty. Lastly, there is a need to put in place effective forest monitoring mechanisms so as to avoid any future repeat of encroachments and illegal settlements in the forest.

\section{Conclusion}

From the study findings, we conclude that the factors that are more likely to motivate the people to move into the Mau Forest included population pressure, laxity on implementation of laws and policies, and insecure land tenure and politics. Additionally, the findings provide evidence that land given by the government, poverty and agricultural production add significantly to the people's decision to settle in the Mau forest. The study results also reveal that $60.9 \%$ of the respondents live below the poverty line due to little or no land to farm on as well as low levels of education that lead to scarce or lack of employment opportunities. In light of the various contributing factors to illegal forest settlement, there is a need to streamline effective policies that will yield sustainable solutions. In the forest conservation efforts, we suggest the implementation of participatory policies and laws that support local communities and institutions in the management of forests. We also call for collective action that recognizes land tenure issues when resolving matters pertaining to forest encroachment. Therefore, it is important to understand the context of deforestation and forest degradation in order to formulate comprehensive, effective and feasible forest management plans and policies.

\section{Acknowledgements}

This paper is part of a $\mathrm{PhD}$ research for the first author. Sincere thanks to the African Union Commission for providing the scholarship that enabled me pursue my doctoral studies at the Pan African University Life and Earth Sciences Institute (PAULESI), Ibadan, Nigeria. The authors are also deeply indebted to the African Forest Forum (AFF) for awarding the first author a fellowship under the theme "Assessment of Trends of Impacts of Climate Change on Forest and Tree-Resources and Coping Mechanisms in Africa" in which the authors were able to fully fund and conduct this study. 


\section{Funding}

This work was supported by the Pan African University Life and Earth Sciences Institute (PAULESI) and the African Forest Forum (AFF).

\section{Conflicts of Interest}

The authors declare no conflicts of interest regarding the publication of this paper.

\section{References}

[1] Jenkins, M. and Schaap, B. (2018) Forest Ecosystem Services. https://www.un.org/esa/forests/wp-content/uploads/2018/05/UNFF13_BkgdStudy_ ForestsEcoServices.pdf

[2] Hong, N.T. and Saizen, I. (2019) Forest Ecosystem Services and Local Communities: Towards a Possible Solution to Reduce Forest Dependence in Bach Ma National Park, Vietnam. Human Ecology, 47, 465-476.

https://doi.org/10.1007/s10745-019-00083-x

[3] Mengist, W. and Soromessa, T. (2019) Assessment of Forest Ecosystem Service Research Trends and Methodological Approaches at Global Level: A Meta-Analysis. Environmental Systems Research, 8, 1-18. https://doi.org/10.1186/s40068-019-0150-4

[4] Foncha, J.N., Ewule, D.M., Foncha, J.N. and Ewule, D.M. (2020) Community Forest Management: A Strategy for Rehabilitation, Conservation and Livelihood Sustainability: The Case of Mount Oku, Cameroon. Journal of Geoscience and Environment Protection, 8, 1-14. https://doi.org/10.4236/gep.2020.82001

[5] Cheng, S.H., Ahlroth, S., Onder, S., Shyamsundar, P., Garside, R., Kristjanson, P., McKinnon, M.C. and Miller, D.C. (2017) What Is the Evidence for the Contribution of Forests to Poverty Alleviation? A Systematic Map Protocol. Environmental Evidence, 6, 10. https://doi.org/10.1186/s13750-017-0088-9

[6] Rahut, D.B., Behera, B. and Ali, A. (2016) Do Forest Resources Help Increase Rural Household Income and Alleviate Rural Poverty? Empirical Evidence from Bhutan. Forests Trees and Livelihoods, 25, 187-198. https://doi.org/10.1080/14728028.2016.1162754

[7] Sunderlin, W.D., Angelsen, A. and Wunder, S. (2003) Forests and Poverty Alleviation. In: State of the World s Forests, Food and Agriculture Organization, Rome, 61-73. https://www.cifor.org/knowledge/publication/1153

[8] Duguma, L., Atela, J., Minang, P., Ayana, A., Gizachew, B., Nzyoka, J. and Bernard, F. (2019) Deforestation and Forest Degradation as an Environmental Behavior: Unpacking Realities Shaping Community Actions. Land, 8, 26. https://doi.org/10.3390/land8020026

[9] Lim, C.L., Prescott, G.W., De Alban, J.D.T., Ziegler, A.D. and Webb, E.L. (2017) Untangling the Proximate Causes and Underlying Drivers of Deforestation and Forest Degradation in Myanmar. Conservation Biology, 31, 1362-1372. https://doi.org/10.1111/cobi.12984

[10] Khuc, Q., Tran, B.Q., Meyfroidt, P. and Paschke, M.W. (2018) Drivers of Deforestation and Forest Degradation in Vietnam: An Exploratory Analysis at the National Level. Forest Policy and Economics, 90, 128-141.

https://doi.org/10.1016/j.forpol.2018.02.004 
[11] Kissinger, G., Herold, M. and De Sy, V. (2012) Drivers of Deforestation and Forest Degradation: A Synthesis Report for REDD+ Policymakers.

https://www.forestcarbonpartnership.org/sites/fcp/files/DriversOfDeforestation.pdf N_S.pdf

[12] FAO (2009) Hot to Feed the World in 2050: High-Level Expert Forum. http://www.fao.org/fileadmin/templates/wsfs/docs/expert_paper/How_to_Feed_the =World_in_2050.pdf

[13] Senker, P. (2011) Foresight: The Future of Food and Farming, Final Project Report. Prometheus, 29, 309-313. https://doi.org/10.1080/08109028.2011.628564

[14] Nasi, R., Wunder, S. and Campos, J.J. (2002) Forest Ecosystem Services: Can They Pay Our Way Out of Deforestation? https://www.cifor.org/publications/pdf_files/BNasi0201.pdf

[15] Koech, C.K. and Koech, C.K. (2020) Household Factors Affecting the Implementation of Forest Conservation Strategies: A Case of South Nandi Forest, Nandi County, Kenya. Open Journal of Social Sciences, 8, 125-144. https://doi.org/10.4236/jss.2020.86012

[16] Contreras-Hermosilla, A. (2000) The Underlying Causes of Forest Decline. CIFOR Occasional Paper No.30, Bogor, Indonesia. https://www.cifor.org/knowledge/publication/626/

[17] Miyamoto, M. (2020) Poverty Reduction Saves Forests Sustainably: Lessons for Deforestation Policies. World Development, 127, Article ID: 104746. https://doi.org/10.1016/j.worlddev.2019.104746

[18] Global Forest Watch (2021) Global Deforestation Rates \& Statistics by Country. GFW. https://www.globalforestwatch.org/dashboards/country/KEN

[19] Mulinge, W., Gicheru, P., Murithi, F., Maingi, P., Kihiu, E., Kirui, O.K. and Mirzabaev, A. (2015) Economics of Land Degradation and Improvement in Kenya. In: Economics of Land Degradation and Improvement-A Global Assessment for Sustainable Development, Springer International Publishing, Berlin, 471-498. https://doi.org/10.1007/978-3-319-19168-3_16

[20] Kyere-Boateng, R. and Marek, M.V. (2021) Analysis of the Social-Ecological Causes of Deforestation and Forest Degradation in Ghana: Application of the Dpsir Framework. Forests, 12, 1-29. https://doi.org/10.3390/f12040409

[21] Yue, C. and Liu, Y. (2007) Impact of Education on the Income of Different Social Groups. Frontiers of Education in China, 2, 191-200. https://doi.org/10.1007/s11516-007-0016-9

[22] Noack, F. and Larsen, A. (2019) The Contrasting Effects of Farm Size on Farm Incomes and Food Production. Environmental Research Letters, 14, Article ID: 084024. https://doi.org/10.1088/1748-9326/ab2dbf

[23] Perge, E. and Behal, R. (2019) How to Frequently and Accurately Measure Poverty and Forest Dependence? https://doi.org/10.1596/32802

[24] Sugandi, D. and Hamdanah, H. (2019) Effect of Forest Encroachment in Cisangkuy Sub Watershed. IOP Conference Series: Earth and Environmental Science. https://doi.org/10.1596/32802

[25] Geist, H.J. and Lambin, E.F. (2002) Proximate Causes and Underlying Driving Forces of Tropical Deforestation. BioScience, 52, 143-150. https://doi.org/10.1641/0006-3568(2002)052[0143:PCAUDF]2.0.CO;2

[26] Standing, A. and Gachanja, M. (2013) A Corruption Risk Assessment for REDD + in Kenya. Ministry of Environment, Water and Natural Resources Kenya. 
[27] Dang, T.K. (2014) The Governance Capacity of Forest Land Allocation Policy in Vietnam. Wageningen University \& Research, Wageningen. https://edepot.wur.nl/313199

[28] Acheampong, E.O., Macgregor, C.J., Sloan, S. and Sayer, J. (2019) Deforestation Is Driven by Agricultural Expansion in Ghana's Forest Reserves. Scientific African, 5, e00146. https://doi.org/10.1016/j.sciaf.2019.e00146

[29] Ankomah, F., Kyereh, B., Ansong, M. and Asante, W. (2020) Forest Management Regimes and Drivers of Forest Cover Loss in Forest Reserves in the High Forest Zone of Ghana. International Journal of Forestry Research, 2020, 1-14. https://doi.org/10.1155/2020/8865936

[30] Coomes, O.T., Takasaki, Y. and Rhemtulla, J.M. (2017) What Fate for Swidden Agriculture under Land Constraint in Tropical Forests? Lessons from a Long-Term Study in an Amazonian Peasant Community. Journal of Rural Studies, 54, 39-51. https://doi.org/10.1016/j.jrurstud.2017.06.002

[31] Debel, F., Tilahun, U. and Chimdesa, D. (2014) The Impact of Population Growth on Forestry Development in East Wollega Zone: The Case of Haro Limu District. Journal of Natural Sciences Research, 4, 85-92. https://www.iiste.org

[32] Iftekhar, M.S. and Hoque, A.K.F. (2005) Causes of Forest Encroachment: An Analysis of Bangladesh. GeoJournal, 62, 95-106. https://doi.org/10.1007/s10708-005-7917-Z

[33] Southall, R. (2005) The Ndungu Report: Land \& Graft in Kenya. Review of African Political Economy, 32, 142-151.

http://mokoro.co.uk/wp-content/uploads/ndungu_report_land_and_graft_in_keny a1.pdf

[34] Kariuki, F. and Ng'etich, R. (2016) Land Grabbing, Tenure Security and Livelihoods in Kenya. African Journal of Legal Studies, 9, 79-99. https://doi.org/10.1163/17087384-12340004

[35] Palmer, D., Fricska, S., Wehrmann, B., Augustinus, C., Munro-Faure, P., Törhönen, M.-P. and Arial, A. (2009) Towards Improved Land Governance: Land Tenure Working. 11. http://www.fao.org/3/ak999e/ak999e.pdf 